\title{
Voluntary Intake and Apparent Digestibility of Artificially Dried Stargrass Fed to Holstein Bull Calves $^{1}$
}

\author{
J.A. Yazman, J.A.Arroyo-Aguilú, R. E. McDowell, P. J. Van Soest, \\ and H. Cestero ${ }^{2,3}$
}

\begin{abstract}
Voluntary intake and apparent digestibility of an artificially dried tropical grass, Cynodon nlemfuensis variety nlemfuensis, was evaluated utilizing Holstein bull calves. Two regrowth ages of grass hays, 30 and 45 days, were fed to two groups of four calves each: 16 and 24 weeks old. The grass hays were analyzed for dry matter and crude protein and for fiber fractions according to Goering and Van Soest.

There were no significant differences between means for voluntary intake $(\mathrm{g} / \mathrm{kg}$ body weight (BW)/day) of the chemical constituents for the four calfhay groups. However, the trend was for higher intake by the 24-week old calves fed the 30-day hay than by the other three groups. Among the 16week old calves, there was a higher voluntary intake by those consuming the 45-day hay despite the slightly higher nutritive value of the 30-day hay.

When the data were pooled across calf ages, voluntary intake of 30 -day hays was greater than for the 45-day ones, although only differences in crude protein intake were significant $(P<.05)$. Pooled across hay ages, voluntary intake by the 24-week old calves was significantly greater $(\mathrm{P}<$ .05) than by the 16-week old calves for dry matter and neutral-detergent fiber only, indicating that hay intake was related to reticulo-ruminal capacity.

Differences in apparent digestibility were significant $(P<.05)$ only for crude protein with the 24-week old calves fed the 30-day hay, having a greater coefficient of digestibility than the 16- and 24-week old calves fed the 45-day hay. Crude protein digestibility of the 30-day hays (pooled across calf ages) was significantly greater $(P<.05)$ than that of the 45 -day hays. Although not significant for all constituents, the values were higher for the 30-day hay than for the 45-day hay (pooled across calf ages) and for the 24week old calves than for the 16-week old calves (pooled across hay ages).
\end{abstract}

\section{INTRODUCTION}

Traditional feeding practices for dairy replacement females in Puerto Rico center around the heavy use of imported concentrate feeds and milk-replacers. With rapidly increasing costs for transportation and rising demands for feed grains, dairymen find that feed costs during

${ }^{1}$ Manuscript submitted to Editorial Board Oct. 26, 1976.

${ }^{2}$ Data are taken in part from a thesis submitted by the senior author to the Graduate Faculty, Cornell University, Ithaca, N. Y., in partial fulfillment of the requirements for the degree of Master of Science.

${ }^{3}$ Graduate Assistant, Department of Animal Science, Cornell University, Ithaca, N.Y.; Associate Nutritionist, Animal Husbandry Department, Agricultural Experiment Station, University of Puerto Rico, Río Piedras, P.R.; Professors of International Animal Science and Animal Nutrition, Department of Animal Science, Cornell University, Ithaca, N.Y.; and Associate Animal Husbandman, Agricultural Experiment Station, University of Puerto Rico, Río Piedras, P.R., respectively. 
the non-productive period of calfhood are becoming a high proportion of the total cost of producing a lactating heifer.

Very little attention has been given to the use of well-managed grass forages as a significant part of the calf diet. In the United States, where milk and feed grains are periodically in surplus, the emphasis has been on increased use of low-fiber diets and decreased use of forages (14). At the same time, reports have shown that the young calf makes efficient use of forage dry matter (DM) as young as 3 weeks of age $(5,9)$.

There has been much research in Puerto Rico on the management of tropical grass species for maximum yield of digestible nutrients (20). One species which has shown promise in grazing studies (3) is stargrass (Cynodon nlemfuensis variety nlemfuensis).

Stargrass is a stoloniferous perennial that is propagated vegetatively. It is gaining popularity as a grazed forage for beef and dairy production due to its ease of cultivation, high yield, and ability to recover under the stress of grazing and harvest.

The objective of this investigation was to measure voluntary intake and apparent digestibility of stargrass hay at two stages of growth in Holstein bull calves of two ages.

\section{PROCEDURE}

This study was conducted at the University of Puerto Rico Agricultural Experiment Substation at Gurabo, located $38 \mathrm{~km}$ south of San Juan at lat. $18^{\circ} 16^{\prime} \mathrm{N}$. and long. $66^{\circ} 12^{\prime} \mathrm{W}$. at an approximate elevation of $76 \mathrm{~m}$.

Average yearly rainfall is $1.65 \mathrm{~m}$, August and September being the months of heaviest rainfall and February and March the months of lightest rainfall. Average maximum temperature is $30^{\circ} \mathrm{C}$, with an average minimum temperature of $18^{\circ} \mathrm{C}$.

Thirty. and 45-day stargrass hays were harvested by hand from a single .28 ha plot. The soil was of the Mabí series. Fertilization was applied at the rate of $2240 \mathrm{~kg} / \mathrm{ha} /$ year of a $15-5-10$ complete fertilizer divided in four equal applications at quarterly intervals. Lime was applied at the rate of $2240 \mathrm{~kg} / \mathrm{ha} /$ year.

Height at all cuttings was approximately $.05 \mathrm{~m}$. Each cutting was performed in the morning and collected in the afternoon. The grasses were dried as a single batch under forced air $\left(45^{\circ} \mathrm{C}\right)$ for approximately $20 \mathrm{~h}$. The dried material was loosely piled for storage in an open-sided barn.

Two groups of four Holstein bull calves, 16 and 24 weeks old, were fed 30- and 45-day stargrass hays with a $22 \%$ crude protein (CP) concentrate mixture in pens for 10 days prior to being placed in 
metabolism crates. Four groups resulted, each with two calves assigned: 1) 16-week calf/30-day hay (16-30); 2) 16-week calf/45-day hay (16-45); 3) 24-week calf/30-day hay (24-30); 4) 24-week calf/45-day hay (24-45). Each trial was replicated twice, with calves assigned to the 30-day hay in trial 1 switched to the 45-day hay in trial 2.

To prevent a protein deficiency, a soybean meal supplement-dehulled, solvent extracted, $56 \%$ crude protein-was fed according to group:

$\begin{array}{cc}\text { Group } & \begin{array}{c}\text { Amount fed } \\ \text { (g/day) }\end{array} \\ 16-30 & 225 \\ 16-45 & 450 \\ 24-30 & 450 \\ 24-45 & 900\end{array}$

Calves were fed and measurements were made twice daily over a 7day experimental period which followed a 10-day adjustment period. The hay was fed in sufficient quantity to allow maximum opportunity for selection and voluntary intake (VI). Daily grab samples were taken and composited for analyses. Orts and feces were totally collected prior to each feeding, sampled and composited for laboratory analyses.

$\mathrm{DM}$ was determined in forage and feces by direct oven-drying at $100^{\circ}$ $\mathrm{C}$ for $12 \mathrm{~h}$. $\mathrm{CP}$ was determined as $\mathrm{N} \times 6.25$ by macro Kjeldahl digestion and distillation using $4 \%$ boric acid as the receiving medium $(1,15)$.

Goering and Van Soest's techniques (7) for cell-wall constituents or neutral-detergent fiber (NDF), acid-detergent fiber (ADF), permanganate lignin (L), cellulose (C), and silicon (Si) were employed. Hemicellulose $(\mathrm{H})$ was determined as the difference between NDF and ADF.

Data were statistically analyzed according to Snedecor and Cochran (17). Significance among group means was obtained by the Scheffe's criterion (16).

\section{RESULTS AND DISCUSSION}

CHEMICAL COMPOSITION OF GRASS HAY

Chemical constituents of the two cuttings of stargrass hay are presented in table 1. Despite uniform procedures in hay management and harvest, the 45-day hay had a lower DM content (78.9\%) than the 30 -day hay $(89.2 \%)$. As the entire yield of the .28 -ha tract was dried in one batch for each cutting, the greater mass of the 45-day hay most likely reduced the hot-air circulation through the drier, thus lowering the amount of moisture removed.

CP content declined $3.4 \%$ while NDF increased $1.5 \%$ between 30 - and 
TABLE 1.-Chemical composition (percentage) of stargrass hay

\begin{tabular}{lrrr}
\hline \multirow{2}{*}{ Constituent } & \multicolumn{2}{c}{ Hay age-days } & Percent change \\
\cline { 2 - 3 } & 30 & 45 & -11.5 \\
\hline Dry matter & 89.2 & 78.9 & 0 \\
Organic matter & 90.6 & 90.6 & 2.1 \\
Neutral-detergent fiber & 70.9 & 72.4 & .26 .6 \\
Crude protein & 12.8 & 9.4 & 20.0 \\
Acid-detergent protein ${ }^{2}$ & 1.0 & 0.8 & 3.5 \\
Acid-detergent fiber & 40.2 & 41.6 & .3 \\
Hemicellulose & 30.7 & 30.8 & 2.5 \\
Cellulose & 32.4 & 33.6 & 3.8 \\
Permanganate lignin & 5.3 & 5.5 & -3.8 \\
Silica & 2.6 & 2.5 & -7.1 \\
Acid-detergent ash & 2.8 & 2.6 & \\
\hline
\end{tabular}

$1 \%$ change $=\frac{(45 \text { day }-30 \text { day })}{30 \text { day }} \times 100$

$2 \%$ Acid detergent protein $=\frac{(\mathrm{N} \text { in acid-detergent fiber } \times 6.25)}{(\text { Dry matter })} \times 100$

TABLE 2. - Voluntary intake (g/kg BW/day) of chemical constituents for two calf ages and two hay ages of stargrass

\begin{tabular}{ccccccccc}
\hline \multirow{2}{*}{ Calf age } & \multirow{2}{*}{ Hay age } & \multicolumn{7}{c}{ Chemical constituents } \\
\cline { 5 - 9 } & & DM' & CP & NDF & OM & ADF & H & C \\
\hline Weeks & Days & & & & & & & \\
16 & 30 & 18.0 & 2.5 & 12.6 & 16.3 & 7.0 & 5.5 & 5.7 \\
& 45 & 18.4 & 1.9 & 13.1 & 16.5 & 7.5 & 5.6 & 6.1 \\
24 & 30 & 23.1 & 3.0 & 16.3 & 20.8 & 9.1 & 7.2 & 7.4 \\
& 45 & 18.5 & 1.9 & 13.3 & 16.6 & 7.5 & 5.6 & 6.1 \\
\hline
\end{tabular}

${ }^{1} \mathrm{DM}$, dry matter; CP, crude protein; NDF, neutral-detergent fiber; OM, organic matter; $\mathrm{ADF}$, acid-detergent fiber; $\mathrm{H}$, hemicellulose; $\mathrm{C}$, cellulose.

45-day hays. There were only small increases in NDF, ADF, H, C, and L, while Si and ash showed small declines.

The low ADF protein content in both hays indicates that the drying process did not result in any significant heat damage (6).

\section{VOLUNTARY INTAKE OF CHEMICAL CONSTITUENTS}

For all chemical constituents, there were no significant differences in rate of intake $(\mathrm{g} / \mathrm{kg} \mathrm{BW} /$ day) for the four groups. The trend was for higher intake by the 24-30 group (table 2). For DM, NDF, OM, and ADF intake in $\mathrm{g} / \mathrm{kg} \mathrm{BW} \cdot 75 /$ day, VI by the 24-30 group was significantly greater $(\mathrm{P}<.05)$ than that of both the $16-30$ and $16-45$ groups, but not significantly greater than the 24-45 group. Among the 16-week old calves, the:e was higher intake by those consuming the 45-day hay despite the higher nutritive value of the 30-day hay. The reason tended 
to be the greater variation in intake among the younger calves who, previous to the experiment, were not exposed to a forage diet. Hodgson (8) found a similar difficulty in obtaining a consistent response from 12 -week old calves to addition and removal of rumen contents through a fistula.

When the intake values were pooled across hay age and calf age (table 3), the greater CP intake by calves consuming the 30-day hay and that of DM and NDF consumed by 24 -week old calves was significant $(\mathrm{P}<.05)$. The significance of the $\mathrm{CP}$ intake is largely a result of the wide difference between the two grass hays in CP content (table 1). Mertens (12) evaluated intake data from 126 grasses and 61 legumes in cows, steers and sheep. He found that the NDF content in grasses causes DM intake to be limited by reticulo-ruminal capacity as opposed to metabolic limitations on energy intake when legumes, low

TABLE 3. - Voluniary intake ( $/ \mathrm{kg}$ BW/day) of chemical constituents pooled across hay and calf ages

\begin{tabular}{lccccccc}
\hline \multirow{2}{*}{ Age } & \multicolumn{7}{c}{ Chemical constituents } \\
\cline { 2 - 8 } & DM $^{1}$ & CP & NDF & OM & ADF & H & C \\
\hline Hay (days) & & & & & & & \\
30 & 20.6 & $2.8 \mathrm{a}$ & 14.4 & 18.5 & 8.1 & 6.4 & 6.6 \\
$\quad 45$ & 18.4 & $1.9 \mathrm{~b}$ & 13.2 & 16.6 & 7.5 & 6.2 & 6.1 \\
Calf (weeks) & & & & & & & \\
16 & $18.2 \mathrm{a}^{2}$ & 2.2 & $12.8 \mathrm{a}$ & 16.4 & 7.3 & 5.6 & 5.9 \\
24 & $20.8 \mathrm{~b}$ & 2.5 & $14.8 \mathrm{~b}$ & 18.7 & 8.3 & 6.5 & 6.8 \\
\hline
\end{tabular}

${ }^{1} \mathrm{DM}$, dry matter; $\mathrm{CP}$, crude protein; NDF, neutral-detergent fiber; OM, organic matter; $\mathrm{ADF}$, acid-detergent fiber; $\mathrm{H}$, hemicellulose; $\mathrm{C}$, cellulose.

${ }^{2}$ Mean values in the same column with one or more letters in common do not differ significantly at the $5 \%$ level.

in NDF, are consumed. Therefore, the greater DM and NDF intake by 24-week old calves was probably due to a greater reticulo-ruminal capacity.

The intake values in table 3 are generally in the reported ranges. Lonsdale et al. (11) fed 12-week old steers artificially dried and chopped $\mathrm{S}-27$ ryegrass (Lolium perenne) and reported an intake of $2.72 \mathrm{~kg} / 100$ $\mathrm{kg}$ BW. This compares with 30 -day stargrass hay which was consumed by the two-calf groups at $2.06 \mathrm{~kg} / 100 \mathrm{~kg} \mathrm{BW}$ when fed in the long form. Consumption of both hays by the 24 -week old calves was $2.08 \mathrm{~kg} / 100$ $\mathrm{kg}$ BW. The physical form of the tropical grass hay, long cut, as compared to the chopped temperate grass hay would tend to lower intake. The lower intake of the tropical grass is consistent with data reported by Tessema (18), when orchardgrass was compared (Dactylis glomerata) with guineagrass (Panicum maximum). This follows the 
theories of Van Soest (19) and Mertens (12), which propose that higher NDF should result in lower intake.

\section{APPARENT DIGESTIBILITY OF CHEMICAL CONSTITUENTS}

Results for apparent digestibility of chemical constituents by calf age-cutting age groups are presented in table 4. With the exception of $\mathrm{CP}$, there were no significant differences in apparent digestibility of any constituent between the four groups. Between the two 24-week old calf groups, there was a trend toward higher apparent digestibility with 30-day hay intake. Except in the case of CP, the 16-week old calves tended to digest the 45-day hay to a greater extent than the 30 day hay, a relationship similar to that for intake in table 2. The differences in apparent digestibility between the two hays for the 16week old calf groups may be due more to variation among animals than to an age effect at harvest.

TABLE 4. - Apparent digestibility (percentage) of chemical constituents for two calf ages and two hay ages of stargrass

\begin{tabular}{ccccccccc}
\hline \multirow{2}{*}{$\begin{array}{c}\text { Calf } \\
\text { age }\end{array}$} & $\begin{array}{c}\text { Hay } \\
\text { age }\end{array}$ & \multicolumn{7}{c}{ Chemical constituents } \\
\cline { 5 - 9 } Weeks & Days & DM & CP & NDF & OM & ADF & H & C \\
\hline 16 & 30 & 60.1 & $58.6 \mathrm{ab}^{2}$ & 65.0 & 61.8 & 55.4 & 77.6 & 67.8 \\
& 45 & 60.5 & $41.3 \mathrm{a}$ & 66.4 & 62.7 & 58.3 & 78.9 & 70.6 \\
24 & 30 & 66.3 & $67.0 \mathrm{~b}$ & 69.6 & 69.6 & 61.9 & 79.4 & 72.9 \\
& 45 & 60.4 & $46.0 \mathrm{a}$ & 65.5 & 62.7 & 57.8 & 75.3 & 70.8 \\
\hline
\end{tabular}

${ }^{1} \mathrm{DM}$, dry matter; CP, crude protein; NDF, neutral-detergent fiber; OM, organic matter; $\mathrm{ADF}$, acid-detergent fiber; $\mathrm{H}$, hemicellulose; $\mathrm{C}$, cellulose.

${ }^{2}$ Mean values in the same column with one or more letters in common do not differ significantly at the $5 \%$ level.

Values for apparent digestibility of the chemical constituents of the two hays were pooled across hay ages and across calf ages (table 5). The 24-week old calves showed higher apparent digestibilities of all chemical constituents except $H$. Chemical constituents of the 30-day hays were digested to a greater extent than those of the 45-day hays. The significance of the higher apparent CP digestibility by the 24-30 calves (table 4) and by calves consuming the 30-day hay (table 5) is questionable due to the dilution effect of metabolic fecal nitrogen.

Reported values for apparent digestibility $(2,13,18)$ of chemical constituents for hay and artificially-dried grass vary widely. Sources of variation within species of grass include species of experimental animal, level of intake, method of preparation, cutting interval, and laboratory method used for analysis. These factors are of questionable validity when comparisons between reports are made. Nonetheless, the values 
from this study, $63.2 \%$ for the 30 -day and $60.4 \%$ for the 45 -day grass hays, fall within the ranges reported. In Trinidad (2), Stargrass hay prepared from regrowth cuttings of ages 3,4 , and 5 weeks had apparent DM digestibilities of $63.2,63.7$ and $60.9 \%$, respectively, when fed to wethers.

In Puerto Rico, Oporta-Téllez (13) compared NDF digestibilities from 30-, 45-, and 60-day guinea- and merker- (Pennisetum purpureum) grass hays in sheep, goats, and steers. NDF digestibilities in steers fed guineagrass hays were $61.2,57.7$, and $59.7 \%$, with an average across hays of $59.5 \%$. The corresponding values for merkergrass hays were $60.3,60.2$, and $58.2 \%$ and averaged $59.6 \%$ across hays. Oporta-Téllez's (13) values were all lower than the NDF apparent digestibilities in this study ( $67.3 \%$ for 30 -day and $65.9 \%$ for 45 -day hays). On the other hand, Oporta-Téllez (13) restricted intake by feeding $90 \%$ of the level of VI

TABLE 5. - Apparent digestibility (percentage) of chemical constituents pooled across hay and calf ages

\begin{tabular}{|c|c|c|c|c|c|c|c|}
\hline \multirow{2}{*}{ Age } & \multicolumn{7}{|c|}{ Chemical constituents } \\
\hline & $\mathrm{DM}^{1}$ & $\mathrm{CP}$ & NDF & OM & $\mathrm{ADF}$ & $\mathrm{H}$ & C \\
\hline \multicolumn{8}{|l|}{ Hay (days) } \\
\hline 30 & 63.2 & $62.8 \mathrm{a}^{2}$ & 67.3 & 65.7 & 58.7 & 78.5 & 70.3 \\
\hline 45 & 60.4 & $43.6 \mathrm{~b}$ & 65.9 & 62.7 & 58.0 & 76.6 & 70.7 \\
\hline \multicolumn{8}{|c|}{ Calf (weeks) } \\
\hline 16 & 60.3 & 49.9 & 65.7 & 62.2 & 56.9 & 77.7 & 69.2 \\
\hline 24 & 63.3 & 56.5 & 67.5 & 66.1 & 59.8 & 77.3 & 71.9 \\
\hline
\end{tabular}

' DM, dry matter; $\mathrm{CP}$, crude protein; NDF, neutral-detergent fiber; OM, organic matter; ADF, acid-detergent fiber; $\mathrm{H}$, hemicellulose; $\mathrm{C}$, cellulose.

${ }^{2}$ Mean values in the same column with one or more letters in common do not differ significantly at the $5 \%$ level.

determined in a preliminary period. Presumably this forced the experimental animals to consume material that they would have avoided, if they had been allowed to select freely with a higher level of feeding $(10,18)$. Also, Oporta-Téllez's (13) forages were sun-dried, therefore possibly somewhat lower in quality $(4,21)$.

Despite the higher consumption of both hays by the 24 -week calves, this study indicates that artificially dried stargrass hay can make a significant contribution to the nutrition of Holstein calves as early as 16 -weeks of age. Since the results of this study show no significant difference between the 30- and 45-day hays as to intake and apparent digestibility, the depression in forage quality (decreased $\mathrm{CP}$ and increased NDF and ADF over the 15-day interval) is not enough to warrant cutting at more frequent intervals. The higher yields expected from the 45-day cutting interval (20) and the lower costs involved ( 8 vs. 


\section{2 cuttings per year) would make highly preferable the longer cutting interval.}

\section{RESUMEN}

El consumo voluntario y la digestibilidad aparente de henos de yerba Estrella (Cynodon nlemfuensis variedad nlemfuensis) se evaluaron alimentando becerros de la raza Holstein. Ocho becerros entre 16 y 24 semanas de edad se alimentaron con henos de yerbas de 30 y 45 días de edad. Se efectuaron determinaciones químico-analíticas de materia seca y de proteína bruta por el método de la AOAC y de las fracciones fibrosas por el método de Goering y Van Soest en las muestras de henos y de heces.

No se obtuvieron diferencias significativas entre promedios de consumo voluntario de las fracciones químicas en los 4 grupos. Sin embargo, la tendencia fue para un mayor consumo por el grupo de becerros de 24 semanas de edad consumiendo henos de 30 días (grupo 24-30) que para los otros 3 grupos. Entre los becerros de 16 semanas de edad hubo un consumo voluntario mayor para el heno de 45 días, aunque el valor nutritivo del heno de 30 días fue superior.

Independientemente de la edad de los becerros, el consumo voluntario de los constituyentes químicos del heno de 30 días fue mayor que el del heno de 45 días, aunque sólo el de proteína bruta fue significativo $(\mathrm{P}<.05)$. Independientemente de la edad de los henos, el consumo voluntario de los becerros de 24 semanas fue significativamente $(\mathrm{P}<.05)$ mayor que el de los becerros de 16 semanas para materia seca y fibra neutrodetergente solamente. Esto indica que el consumo de heno está relacionado con la capacidad retículo-ruminal.

Las diferencias en digestibilidad aparente en el grupo 24-30 fueron significativas ( $P$ $<.05$ ) sólo para proteína bruta, presentando un coeficiente de digestibilidad mayor que en los grupos 16-45 y 24-45. La digestibilidad de la proteína bruta del heno de 30 días fue significativamente $(\mathrm{P}<.05)$ mayor que la del de 45 días. Aûnque no fueron significativos para todas las fracciones, la digestibilidad fue mayor en el heno de 30 días que en el de 45 días y en los becerros de 24 semanas que en los de 16 semanas.

\section{LITERATURE CITED}

1. Association of Official Analytical Chemists, Official Methods of Analysis, 11th ed, Washington, D.C., 1970.

2. Butterworth, M. H., The digestibility of tropical grasses, Nutr. Abstr. Rev. 37: 34968, 1967.

3. Caro-Costas, R., Abruna, F., and Vicente-Chandler, J., Comparison of heavily fertilized Pangola and Star grass pastures in terms of beef production and carrying capacity in the humid mountain region of Puerto Rico, J. Agric. Univ. P.R. 56(2): 104-9, 1972.

4. Demarquilly, C., and Jarrige, R., The effect of method of forage conservation on digestibility and voluntary intake, Proc. XI Inter. Grassland Cong. 733-6, 1970.

5. Godfrey, N. W., The functional development of the calf. I. Growth of the stomach of the calf, J. Agric. Sci. 57: 173-5, 1961.

6. Goering, H. K., and Van Soest, P. J., Effect of moisture, temperature and pH on the relative susceptibility of forages to non-enzymatic browning, Abstr., J. Dairy Sci. 50: 989-90, 1967.

7. - and - Forage fiber analyses (apparatus, reagents, procedures and some applications), USDA Agric. Handbook 379, 1970.

8. Hodgson, J., The development of solid food intake in calves 4. The effect of the addition of material to the rumen, or its removal from the rumen, on voluntary food intake, Anim. Prod. 13: 581-92, 1971.

9. Kang, H. S., and Leibholz, J., The roughage requirement of the early-weaned calf, Anim. Prod. 16: 195-203, 1973.

10. Lindahl, I. L., Mothods employed in nutrition research, In Techniques and proce- 
dures in animal production research, Amer. Soc. Anim. Prod.: 173-83, 1959.

11. Lonsdale, C. R., Pontiainen, E. K., and Tayler, J. C., The growth of young cattle fed on dried grass alone and with barley. 1. Feed intake digestibility and body gains, Anim. Prod. 13: 461-71, 1971.

12. Mertens, D. R., Application of theoretical mathematical models to cell wall digestion and forage intake in ruminants, Ph.D. Thesis, Cornell Univ., 1973.

13. Oporta-Téllez, J. A., Composición química y digestibilidad in vivo e in vitro de los henos de Guinea (Panicum maximum Jacq.) y Merker (Pennisstum purpureum Schum.), M.S. Thesis, Univ. P.R., 1973.

14. Porter, J. C., The effect of fiber level and physical form of the concentrate on the growth and development of dairy calves fed no forage, M.S. Thesis, Cornell Univ., 1973.

15. Scales, F. M., and Harrison, H. E., Boric acid modification of the Kjeldahl method for crop and soil analyses, J. Ind. Eng. Chem. 12: 350-2, 1920.

16. Scheffe, J., The analysis of variance, John Wiley \& Sons, New York, N.Y., 1959.

17. Snedecor, G. W., and Cochran, W. G., Statistical methods, 6th ed, The Iowa State Univ. Press, Ames, Iowa, 1967.

18. Tessema, S., Nutritional value of some tropical grass species compared to some temperate grass species, Ph.D. Thesis, Cornell Univ., 1972.

19. Van Soest, P. J., Symposium on factors influencing the voluntary intake of herbage by ruminants: Voluntary intake in relation to chemical composition and digestibility, J. Anim. Sci. 24: 834-43, 1965.

20. Vicente-Chandler, J., Abruña, F., Caro-Costas, R., Figarella, J., Silva, S., and Pearson, R. W., Intensive grassland management in the humid tropics of Puerto Rico, Agric. Exp. Sta. Univ. P.R. Bull. 233, 1974.

21. Wilson, R. K., and McCarrick, R. B., Apparent dry matter digestibility, voluntary food intake and yields of dry matter of mixed swards conserved as artificially dried grass and tetrapod hay, at progressive stages of maturity. Proc. 10 Inter. Grassland Cong. 371-3, 1966. 